\title{
SMOKING HABIT, PHYSICAL ACTIVITY AND HYPERTENSION AMONG MIDDLE AGED MEN
}

\author{
Kebiasaan Merokok, Aktivitas Fisik, dan Hipertensi pada Laki-laki Dewasa \\ Rian Diana $^{1 *}$, Ali Khomsan², Naufal Muharam Nurdin ${ }^{3}$, Faisal Anwar ${ }^{4}$, Hadi Riyadi ${ }^{5}$ \\ ${ }^{1 *}$ Department of Nutrition, Faculty of Public Health, Universitas Airlangga, Surabaya, Indonesia \\ ${ }^{2-5}$ Department of Community Nutrition, Faculty of Human Ecology, Bogor Agricultural University, Bogor, Indonesia \\ E-mail: rian.diana@fkm.unair.ac.id
}

\begin{abstract}
Hypertension is a global public health problem. Hypertension prevalence increasing with age, particularly in middle aged men. It is important to identify the modifiable risk factors. The aim of this study was to analyse the correlation of smoking habit, physical activity, and hypertension among middle aged men. This study was conducted in Cianjur District, West Java. 112 men aged 45-59 years old were participated in this cross sectional study. Automatic blood pressure (OMRON Model HEM-7200) was used to measure blood pressure. 24-hour physical activity recall was used to assess physical activity (PA). The correlation between smoking habit and hypertension was analyzed by Chi Square. The correlation between physical activity and hypertension was analyzed by Spearman. This study found that 83.9\% subjects had smoking habit. More than half of the subjects (57.2\%) had heavy PA. Almost half of the subjects (43.7\%) were hypertension. Median of systolic $135.0 \mathrm{mmHg}$ and diastolic $85.0 \mathrm{mmHg}$. There was a significant correlation between smoking habit $(p=0.039)$ and physical activity $(p=0.025)$ with hypertension. Smoking habit and physical activity correlate with hypertension. Having a moderate to vigorous physical activity regularly particularly in smokers among middle aged men are recommend for decreasing the prevalence of hypertension.
\end{abstract}

Keywords: blood pressure, middle aged men, physical activity, smoking

\begin{abstract}
ABSTRAK
Hipertensi merupakan masalah kesehatan masyarakat secara global. Prevalensi hipertensi meningkat seiring dengan peningkatan usia khususnya pada laki-laki dewasa. Oleh karena itu penting untuk mengidentifikasi faktor risiko yang dapat dimodifikasi. Tujuan dari penelitian ini adalah menganalisis hubungan antara kebiasaan merokok, aktivitas fisik dengan hipertensi pada laki-laki dewasa. Penelitian ini dilakukan di Kabupaten Cianjur, Jawa Barat. Sebanyak 112 laki-laki berusia 45-59 tahun berpartisipasi dalam penelitian cross sectional ini. Tekanan darah diukur menggunakan tensimeter automatic merk OMRON Model HEM-7200. Aktivitas fisik dinilai dengan menggunakan recall 24 jam aktivitas fisik. Hubungan antara kebiasaan merokok dengan hipertensi dianalisis menggunakan Chi Square. Hubungan antara aktivitas fisik dengan hipertensi menggunakan Spearman. Hasil penelitian menunjukkan bahwa $83,9 \%$ subyek memiliki kebiasaan merokok. Lebih dari separuh subyek $(57,2 \%)$ memiliki aktivitas fisik yang berat. Hampir separuh $(43,7 \%)$ tergolong hipertensi. Median sistolik adalah $135,0 \mathrm{mmHg}$ dan diastolik $85,0 \mathrm{mmHg}$. Terdapat hubungan yang signifikan antara kebiasaan merokok $(\mathrm{p}=0,039)$ dan aktivitas fisik $(\mathrm{p}=0,025)$ dengan hipertensi. Disarankan melakukan aktivitas fisik yang sedang dan berat secara rutin khususnya pada perokok laki-laki dewasa untuk menurunkan prevalensi hipertensi.
\end{abstract}

Kata kunci: tekanan darah, laki-laki dewasa, aktivitas fisik, kebiasaan merokok

\section{INTRODUCTION}

Hypertension is a global public health problem. One out of four people in Indonesia had hypertension. Hypertension is not only present in urban area but also in rural area. It can be seen from the prevalence that almost the same with national prevalence (Ministry of Health, 2013). Hypertension $(\geq 140 / 90 \mathrm{mmHg})$ prevalence increasing with age, particularly in middle aged people (Ministry of Health, 2013). People aged

Rian Diana, et al., MGI(2018) 57-61

DOI: $10.20473 /$ mgi.v13i1.57-61. 
45-54 years were 12.7 times more likely to develop hypertension than people aged 18-24 years so it is important to identify the modifiable risk factors (Yang et al., 2016).

Lifestyle factors such as smoking habit and physical activity are important modifiable risk factors for development of hypertension. Physical activity have a benefit effect on prevention of hypertension (Diaz \& Shimbo, 2013). Meanwhile, cigarette smoking increase systolic blood pressure and heart rate (Leone, 2015; Gao et al., 2017). In contrast, other study showed there was no differences between smoking status and hypertension prevalence (Pankova et al., 2015; Li et al., 2017). Indonesia Basic Health Survey 2013 showed that men (64.9\%) have a higher proportion of current smokers than women (Ministry of Health, 2013). Those previous studies have shown inconsistent results where there were both inverse and positive associations between cigarette smoking and development of hypertension particularly in men. Therefore this study aimed to investigate the correlation between smoking habit, physical activity, and blood pressure among middle aged men.

\section{METHODOLOGY}

\section{Study Design and Sampling}

This study was a cross sectional study. The study population was middle aged men (45-59 years old) residing in Cisalak and Sukamantri Village, Cianjur District. Based on Oxford dictionary and Merriam Webster dictionary middle aged is the period of life from 45-65 years old. The sample was selected using simple random sampling among middle aged men that agreed to be interviewed and for blood pressure measurement. The sampling frame was composed from family registration form obtained from Cilasak and Sukamantri Village Office. According to Lwanga and Lemeshow (1991) equation, with confidence level $95 \%$, absolute precision 0.05 , and proportion of hypertension among farmers/labour $7.8 \%$ (Ministry of Health, 2013), the minimum sample for this study was 112 subjects. This study conducted in rural area at Cianjur District, West Java, Indonesia in 2014.

\section{Data Collection}

Variables in this study were smoking habit, and high blood pressure history collected through interview with structured questionnaire and done by trained enumerators. Physical activity (PA) was assessed by 24-hour physical activity recall. Blood pressure (BP) was measured by an automatic blood pressure monitor (OMRON Model HEM7200) which was done by medical doctor. BP measurement on the left arm done in the morning (07.00-10.00 AM) at village hall. Sample were given 10-15 minutes of rest since arriving at village hall before the measurement taken.

\section{Data Analysis}

Smoking habit was categorized into 2 groups (smoking and non-smoking). Physical activity level (PAL) was classified into 3 groups, light (PAL $\leq 1.69$ ), moderate (PAL 1.70-1.99), and heavy (PAL $\geq 2.00$ ) (Food and Agricultural Organization, 2001). Based on Joint National Committee 7 on Prevention, Detection, Evaluation, and Treatment of High Blood Pressure, there were 5 category of blood pressure; normal $(<120 / 80 \mathrm{~mm} \mathrm{Hg})$, prehypertension (120-139/80-89 mm Hg), Hypertension $\geq 140 / 90 \mathrm{~mm} \mathrm{Hg}$. This hypertension were divided into 2 stages (stage 1= BP 140$159 / 90-99 \mathrm{~mm} \mathrm{Hg}$ and stage $2=\mathrm{BP} \geq 160 / 100 \mathrm{~mm}$ $\mathrm{Hg}$ ) (National Institutes of Health, National Heart, Lung, 2004). Spearman's Rank correlation was applied to analyse the association between physical activity and hypertension and Chi square was used to correlate smoking habit and hypertension.

\section{RESULTS AND DISCUSSION}

Distribution of the subjects' educations and jobs are presented in Table 1. Most of the subject education level was only up to elementary school $(92.8 \%)$. More than half of the subjects worked as farm laborers (51.8\%). The rest were distributed in various kinds of informal jobs, such as building workers, farmers, and others (tailor, driver, wood cutter, and mechanics). 
Table 1. Subjects Characteristics

\begin{tabular}{lcc}
\hline \multicolumn{1}{c}{ Characteristics } & $\mathbf{n}$ & $\mathbf{\%}$ \\
\hline $\begin{array}{l}\text { Education } \\
\quad 9 \text { years }\end{array}$ & 104 & 92.8 \\
$>9-12$ years & 6 & 5.4 \\
$\quad>12$ years & 2 & 1.8 \\
Occupation & & \\
$\quad$ No job & 6 & 5.4 \\
Farmer (land owner) & 7 & 6.2 \\
Farm laborer & 58 & 51.8 \\
Building laborer & 11 & 9.8 \\
Seller & 8 & 7.1 \\
Civil servant/private worker & 4 & 3.6 \\
Retired & 1 & 0.9 \\
Others & 17 & 15.2 \\
\hline
\end{tabular}

Table 2 showed that majority of the subjects had a smoking habit $(83.9 \%)$. Most of them smoked every day $(93.6 \%)$, they had already awared that smoking endangers their health (79.8\%) and had an intention to stop smoking (73.4\%), but only one third of them whom lower their cigarettes consumption (29.8\%).

Various reasons for stop smoking stated by the subjects were health factors (cough, shortwinded, stroke, avoiding diseases, health getting worse, damaging health), economic factors (reducing expenditure, and not having money), and miscellaneous reasons such as avoiding acts which do not give any benefit according to Islam religion and realizing to have been old. On the other hand $27.9 \%$ of the subjects did not have any intention to stop smoking with the reason that they felt weak, sick, not good, dizzy, and sleepy if they did not smoke, feeling difficult to stop smoking because they were addicted, inhibiting social communication, often being offered cigarettes by other parties, and to get rid of bad smell in the mouth. Many studies revealed that smoking habit can arouse various kinds of diseases, such as respiratory diseases (Jayes et al., 2016), cardiovascular diseases (Mons et al., 2015), high blood pressure (Gao et al., 2017), and cancer (Proctor, 2012).

Based on an 24-hour activity recall during a working day, the subjects activities are varied enough. More than half of the subjects (57.2\%) had heavy physical activities (Table 2). Physical
Table 2. Smoking Habit and Physical Activity

\begin{tabular}{|c|c|c|}
\hline Smoking Habit and Physical Activity & $\mathbf{n}$ & $\%$ \\
\hline \multicolumn{3}{|l|}{ Smoking $(\mathrm{n}=112)$} \\
\hline Yes & 94 & 83.9 \\
\hline No & 18 & 16.1 \\
\hline \multicolumn{3}{|l|}{ Frequency of Smoking $(n=94)$ : } \\
\hline Every day & 88 & 93.6 \\
\hline 2-6 days/week & 5 & 5.3 \\
\hline$\leq$ once a week & 1 & 1.1 \\
\hline \multicolumn{3}{|c|}{ Compared to Last Year, the Number of Cigarettes } \\
\hline \multicolumn{3}{|c|}{ Usually Smoke (n=94) } \\
\hline Lower & 28 & 29.8 \\
\hline Greater & 12 & 12.8 \\
\hline Similar & 54 & 57.4 \\
\hline \multicolumn{3}{|l|}{ Intended to Stop Smoking $(n=94)$ : } \\
\hline Yes & 69 & 73.4 \\
\hline No & 25 & 26.6 \\
\hline \multicolumn{3}{|l|}{ Smoking Can Damage Health $(n=94)$ : } \\
\hline Yes & 75 & 79.8 \\
\hline No & 19 & 20.2 \\
\hline \multicolumn{3}{|l|}{ Physical Activity Level (n=112) } \\
\hline Light $(\mathrm{PAL} \leq 1.69)$ & 33 & 29.4 \\
\hline Moderate (PAL 1.70-1.99) & 15 & 13.4 \\
\hline Heavy (PAL $\geq 2.00)$ & 64 & 57.2 \\
\hline Median (min;max) & \multicolumn{2}{|c|}{$2.1(1.1 ; 3.1)$} \\
\hline
\end{tabular}

activities among the rural people are closely related with their works. Many of the men worked as farm laborers.

The prevalence of high blood pressure can be seen from Table 3. The combination of systolic and diastolic showed the prevalence of hypertension based on Joint National Committee 7 on Prevention, Detection, Evaluation, and Treatment of High Blood Pressure. The prevalence of hypertension among middle aged men in this study was $43.7 \%$ (stage $1=23.2 \%$; stage $2=20.5 \%$ ). The prevalence of prehypertension was also high enough (39.3\%). Prehypertension is very important as a sign to improve education by medical staff and public awareness in order to decrease the blood pressure and to prevent the development of hypertension.

Table 3. Blood Pressure

\begin{tabular}{lcc}
\hline \multicolumn{1}{c}{ Blood Pressure } & n & \% \\
\hline Normal & 19 & 17.0 \\
Prehypertension & 44 & 39.3 \\
Hypertension stage 1 & 26 & 23.2 \\
Hypertension stage 2 & 23 & 20.5 \\
\hline
\end{tabular}


Table 4. Correlation of Smoking Habit and Physical Activity with Blood Pressure [n (\%)]

\begin{tabular}{|c|c|c|c|c|c|c|}
\hline \multirow{2}{*}{ Variable } & \multicolumn{4}{|c|}{ Blood Pressure } & \multirow[b]{2}{*}{ Total } & \multirow{2}{*}{ p-value } \\
\hline & Normal & Prehypertension & Hypertension stage 1 & Hypertension stage 2 & & \\
\hline \multicolumn{7}{|c|}{ Smoking Habit } \\
\hline Yes & $18(19.1)$ & $39(41.5)$ & $22(23.4)$ & $15(16.0)$ & $94(100.0)$ & $0.039^{*}$ \\
\hline No & $1(5.6)$ & $5(27.8)$ & $4(22.2)$ & $8(44.4)$ & $18(100.0)$ & \\
\hline \multicolumn{7}{|c|}{ Physical Activity Level } \\
\hline Light & $1(3.0)$ & $14(42.4)$ & $7(21.2)$ & $11(33.3)$ & $33(100.0)$ & \multirow{3}{*}{$0.025 * *$} \\
\hline Moderate & $2(13.3)$ & $10(66.7)$ & $2(13.3)$ & $1(6.7)$ & $15(100.0)$ & \\
\hline Heavy & $16(25.0)$ & $20(31.3)$ & $17(26.6)$ & $11(17.2)$ & $64(100.0)$ & \\
\hline
\end{tabular}

Note: *analyzed by Chi Square; **analyzed by Spearman's Rank $(\mathrm{r}=-0.212)$

High prevalence of hypertension among middle aged men was found in this study. Compared to basic health survey Indonesia in 2013, the prevalence of hypertension in this study was higher than national prevalence (Ministry of Health, 2013).

In this study, chi square test showed that smoking habit significantly correlated with blood pressure $(p=0.039)$. The smokers had a higher proportion of having normal blood pressure, prehypertension, and hypertension stage 1 than non-smokers. Meanwhile the non-smokers have a higher proportion of having hypertension stage 2 . This study have a contradicting result with other study which stated that smoking habit can increase blood pressure (Leone, 2015; Gao et al., 2017).

Nicotine and carbon monoxide have a toxic effect on the heart and blood vessels. Nicotine can increase catecholamine release so it could increase systolic blood pressure and heart rate. Carbon monoxide can bind with hemoglobin forming carboxyhemoglobin. This carboxyhemoglobin causes tissue hypoxia so it can damage heart and blood vessels (Leone, 2015).

This conflicting result may be caused by the physical activity of the subject. Among the smokers with normal, prehypertension, and hypertension stage 1, majority of the subject have a heavy physical activity. Regular moderate and heavy physical activity can reduce the risk of developing hypertension (Diaz et al., 2017). Tadjalli (2010) discovered that among physically inactive smokers, the odd of hypertension increase 1.74 times greater than non-smokers. Smokers can significantly reduce their odd of developing hypertension by incorporating physical activity in their daily life.

This study found that blood pressure inversely correlated with physical activity $(\mathrm{p}=0.025, \mathrm{r}=$ 0.212 ). Subjects with light physical activity have a higher proportion of getting high blood pressure than moderate and heavy (Table 4). This study in line with review by Diaz and Shimbo which found that physical activity is inversely associated with the development of hypertension (Diaz \& Shimbo, 2013).

Physical activity can prevent the development of hypertension by reducing body weight, vascular resistancies, arterial stiffness, oxidative stress, inflammation, and renin-angiotensin system activity also by enhancing endothelial function, insulin sensitivity, renal function, sodium handling, parasympathetic activity, angiogenesis arteriogenesis, arterial compliance, and arterial lumen diameter (Diaz \& Shimbo, 2013). Correlation of physical activity and blood pressure among smokers can be explored in the future research.

\section{CONCLUSION}

The important finding in this study were hypertension among middle aged men were highly prevalent and hypertension correlate with smoking habit and physical activity. Having a moderate to vigorous physical activity regularly particularly in smokers are recommended for decreasing the prevalence of hypertension. Supported environment are needed to translate the intention into action to quit smoking. 


\section{ACKNOWLEDGEMENT}

We thank to Neys-van Hoogstraten Foundation for funding this study (IN255).

\section{REFERENCES}

Diaz, K.M., Booth, J.N., Seals, S.R., Abdalla, M., Dubbert, P.M., Sims, M., Ladapo, J.A, Redmond, N. Muntner, P., \& Shimbo, D. (2017). Physical activity and incident hypertension in African Americans. Hypertension, 69(3), 421-427. https://doi.org/10.1161/ HYPERTENSIONAHA.116.08398.

Diaz, K.M., \& Shimbo, D. (2013). Physical activity and the prevention of hypertension. National Institute of Health, 15(6), 659-668. https://doi. org/10.1007/s11906-013-0386-8.Physical.

Food and Agricultural Organization. (2001). Human energy requirements: Report of a joint FAO/WHO/UNU expert consultation. FAO Food and Nutrition Technical Report Series, 0 , 96. https://doi.org/92 51052123.

Gao, K., Shi, X., \& Wang, W. (2017). The lifecourse impact of smoking on hypertension, myocardial infarction and respiratory diseases. Scientific Reports, 7(1), 4330. https://doi. org/10.1038/s41598-017-04552-5.

Jayes, L., Haslam, P.L., Gratziou, C.G., Powell, P., Britton, J., Vardavas, C., \& De Grada Orive, J.I. (2016). SmokeHaz: systematic reviews and meta-analyses of the effects of smoking on respiratory health. Chest, 150(1), 164-179. https://doi.org/10.1016/j.chest.2016.03.060.

Leone, A. (2015). Smoking and Hypertension. Journal of Cardiology \& Current Research, 2(2). https://doi.org/10.15406/jccr.2015.02.00057.

Li, G., Wang, H., Wang, K., Wang, W., Dong, F., Qian, Y., Gong, H., Hui, C., Xu, G., Li, Y., Zhang, B., \& Shan, G. (2017). The association between smoking and blood pressure in men: a cross-sectional study. BMC Public Health, 17:797. DOI 10.1186/s12889-017-4802-x.

Lwanga S.K., \& Lemeshow S. (1991). Sample size determination in health studies a practical manual. Geneva: WHO.
Ministry of Health. (2013). Basic Health Survey. Ministry of Health Indonesia.

Mons, U., Muezzinler, A., Gellert, C., Schottker, B., Abnet, C.C., Bobak, M., Groot, L., Freedman, N.D., Jansen, E., Kee, F., \& Brenner, H. (2015). Impact of smoking and smoking cessation on cardiovascular events and mortality among older adults: meta-analysis of individual participant data from prospective cohort studies of the CHANCES consortium. BMJ 350, h.1551. https://doi.org/10.1136/bmj.h1551.

National Institutes of Health, National Heart, Lung, \& B.I. (2004). Complete Report The Seventh Report of the Joint National Committee on Prevention, Detection, Evaluation, and Treatment of High Blood Pressure. Complete Report The Seventh Report of the Joint National Committee on Prevention, Detection, Evaluation, and Treatment of High Blood Pressure. https:// doi.org/10.1111/j.1365-2796.2011.02356.x.

Pankova, A., Kralikova, E., Fraser, K., Lajka, J., Svacina, S., \& Matoulek, M. (2015). No difference in hypertension prevalence in smokers, former smokers and non-smokers after adjusting for body mass index and age: a crosssectional study from the Czech Republic, 2010. Tobacco Induced Diseases, 13(1), 1-7. https:// doi.org/10.1186/s12971-015-0049-4.

Proctor, R.N. (2012). The history of the discovery of the cigarette-lung cancer link: evidentiary traditions, corporate denial, global toll: Table 1. Tobacco Control, 21(2), 87-91. https://doi. org/10.1136/tobaccocontrol-2011-050338.

Tadjalli, S. (2010). Impact of physical activity on the association between smoking and hypertension. (Master's thesis, Georgia State University, Atlanta, USA. Diakses dari https:// scholarworks.gsu.edu/iph_theses/158/.

Yang, G., Ma, Y., Wang, S., Su, Y., Rao, W., Fu, Y., Yu, Y., \& Kou, C. (2016). Prevalence and correlates of prehypertension and hypertension among adults in northeastern China: A cross-sectional study. International Journal of Environmental Research and Public Health, 13(1), 1-12. https://doi.org/10.3390/ijerph13010082. 